\title{
Pluralism and Political Participation of Left-Wing Parties in Jordan
}

\author{
Abdalhaleem Al-Adwan ${ }^{1}$ \\ ${ }^{1}$ Vise Dean of Faculty of Islamic Architecture \& Arts, College of Arts and Sciences, The World Islamic Sciences \\ and Education University, Jordan \\ Correspondence: Abdalhaleem Al-Adwan. E-mail: dr.abdalhaleem6@yahoo.com
}

Received: March 9, 2020 Accepted: May 9, $2020 \quad$ Online Published: December 30, 2020

doi:10.5539/ass.v17n1p77

URL: https://doi.org/10.5539/ass.v17n1p77

\begin{abstract}
The left-wing that includes the nationalist, communist, and Ba'athist parties arose in Jordan with the beginning of the kingdom's independence. Its role in opposing the regime doubled after the unity of the two banks and the integration of the Jordanian left-wing with the Palestinian left-wing, participated with other right and middle currents in all stages of participation in parliamentary and pluralistic elections and the formation of the first pluralist democratic government in 1956, which lasted for less than one year and was the reason for its termination after the relationship with the government system worsened. This trend resorted to clandestine work after the dissolution of the government and the parties until 1989, the regime's transition to democratic pluralism, where it participated in multi-party elections with other party currents, calling for the promotion of the values of pluralism, political participation, and the transfer of power. However, it lacked its application in its internal system.
\end{abstract}

Keywords: Pluralism and Political Participation of Left-Wing Parties

\section{Introduction}

The Mainstream leftist appeared in Jordan after independence in 1946, and it developed in light of the 1952 constitution and the laws of political parties, the last of which is the law of 2015, and because democracy, pluralism, socialism and political participation form one of the pillars of political thought in the systems and programs of the Mainstream leftist, and they are the basis of social, economic, cultural and other relations, the call for respect for opinion and other opinion, respect for public freedoms, and political, administrative, and economic reform became a feature of left and national thought in democracy and pluralism, and it has a political framework that achieves social justice, politics, unity and resistance to colonialism, although it has not often taken part in participation or democracy within its organizations, and it was a reason for the end of participation in 1957, because of its inability and the system in Jordan to coexist or maintain democracy, pluralism and the transfer of power. After 1989, the world witnessed a fundamental change in its international political system. After a series of changes and events on the domestic and international scene, the most important of them is the economic and political crisis that confronted Jordan in 1989 and the collapse of the communist and socialist systems, which directly or indirectly affected the transition to democratic political participation in Jordan. The Political Parties Law and the Election Law were amended more than once after 1992, which allowed all parties to conduct their activities in public, including nationalist and leftist parties. Restricted by government legislation and laws, and it affected these parties' participation in public political life even after the so-called Arab Spring, for reasons including those related to the legislation governing parties and others related to the parties themselves.

\subsection{The Importance of the Study}

The research's importance stems from the fact that many studies that touched on political and democratic participation gave the nationalist and leftist movement in Jordan only a small amount. That may have addressed an aspect of political participation. Its importance also stems from the recognition of the principles, goals, and participation of nationalist and leftist parties in political participation or its restriction to it, highlighting the limiting aspects of the participation of leftist nationalist parties and the extent of its adaptation to the laws of parties and within its organs and internal systems.

\subsection{Study Objectives}

1. To Know and reveal the various essential aspects of the leftist nationalist parties 'orientation towards 
adopting political participation and the political system's position regarding their participation in political life.

2. The extent to which leftist nationalist parties and movements accept participation with other currents and parties transition to participation and democracy.

\subsection{Study Problem}

The study's problem stems from examining the positions of leftist nationalist movements and parties on political participation and linking them with the orientations of the Jordanian political system in allowing political participation.

\subsection{Study Questions}

- Is the leftist shift of political participation an internal choice or an external option?

- Do legislation and laws allow left nationalist parties to participate in politics?

\subsection{The Study Hypothesis}

There is a positive, positive relationship between the regime's response in Jordan to allow leftist and nationalist parties to participate in politics, and between the challenges it faces from the nationalist and leftist parties and regional pressure for this transformation, as a way to get out or mitigate these challenges to strengthen its legitimacy and the continuation of the political system.

\subsubsection{The Concept of Political Participation}

Political participation in the past was mostly restricted to the wealthy, while the overwhelming majority was far from participating. With the development and specifically at the end of the nineteenth century, there was an increased interest in political participation due to increased education, industrialization, and cities' expansion (Eliyah 2008: 12). With the development of communication and transportation, new ideas about democracy and political participation are emerging and spread quickly and efficiently. Its spread increased with the emergence of the conflict between political leaders, which led to the competing forces fighting for the sake of gaining popular support. Which gave legitimacy to the idea of mass participation, in addition to the increased government interference in the social, cultural, and economic affairs that individuals must deal with to depend on their daily lives on government business; without the legal right to political participation, the interests of individuals become threatened in the face of the government. Hence the demand for granting political rights to individuals and creating the possibility of exercising them effectively reduces the government's influence. Therefore, political participation is considered the central pillar of democracy. And a living expression of the values of freedom, justice, and equality in political systems, an important indicator of the development of society and its political system, aims to establish a political system of popular participation and not of the minority.

\subsubsection{Definition of Political Participation}

Political participation has several definitions. The International Knowledge Department for Social Sciences (Al-Harahsheh, 2006, pp. 33-34) defined it as "optional activities according to which members of society participate in choosing their rulers and contribute to making the state's general policy directly or indirectly." As for Samuel Huntington and John Nelson, they defined political participation as "the activity carried out by ordinary citizens with the intent to influence government decision-making, whether this activity is individual or collective, organized or spontaneous, continuous or interrupted, peaceful or violent, legal or illegal," Active or Ineffective (Hunington, 1976, p. 3). And as for Abdel-Moneim Al-Mashat, he defined political participation as "a form of political practice related to the structure of the political system in inputs, whether support or opposition, but it aims to change the outcomes of the political system that suit the demands of individuals and groups who submit to it (Al-Mashat, 1988, p. 306)." There is another definition that considers political participation to be (giving citizens equal opportunities to maintain the form of judgment and to contribute to deciding the fate of their country in the way they want it so that they can formulate the political conditions as they want and so that they can formulate the political conditions in the way they want life under it (El-Baz, 2000, p. 13). We find these definitions emphasize the group's positive role and the individual in political life through the administrative practice of the right to vote and nominate elected bodies or discuss the political act with others by joining the intermediary organizations. Therefore, political participation means those administrative activities undertaken by individuals to directly or indirectly influence the process of selecting rulers, influencing decisions, or the policies they make. It also leads to more stability and order in society, which leads to deepening and widening the sense of the legitimacy of the system, increasing the masses' attachment to the system and its goals, raising the profile of loyalty, influence, and responsibility, eliminating images of abuse of power, and influencing the behavior of 
rulers to act in accordance with the priorities of the masses.

\subsubsection{Definition of Political Parties}

The definitions of political parties are multiple due to the different political and legal trends, and the difference in definitions is due to the multiplicity and different ideologies, and these trends concerned the functions of the parties and the angle from which these parties are viewed. The various definitions came to express several civilizations' adoption for the parties that reflected the thought and social reality in which they lived (Doverje, 1992, pp. 72-74). Some focus on defining the party on the practical side and the ultimate goal of the political process on which the party is based, such as liberal thought. Edmond Burke defines it as saying: "The party is a union of a group of individuals to work together to achieve the national interest in accordance with specific principles agreed upon by all (Al-Khatib, 1983, p. 22). And some focus on defining the party on the class side, focusing on training on the class side, and focusing on the social formation and economic linkage between its members, such as socialist and Marxist thought (Al-Zoubi, 1995, p. 88).

As for Arab thought, we find that jurists approach their definition of a political party to liberal thought; Suleiman Al-Tamawi defines it: "it is a united group of individuals working with various democratic means to win rule to implement a political program." (Al-Tamawi, 1979, p. 22).

In Jordan, the Jordanian Political Parties Law of 1992 did not move away from defining the political party from liberal and Arab thought. The law defines the political party "as every political organization consisting of a group of Jordanians in accordance with the constitution and the provisions of the law to participate in political life, achieving specific goals related to political, economic and social affairs, and operating by legitimate means (Law of Political Parties No. 39 of 2015).

We note from the previous definitions that they differ from the political party's definition in the Jordanian Parties Law. In referring to the fact that the party is seeking to reach power, it believes in the theory of the transfer of power by legitimate and sound means. The Jordanian parties law did not refer to the principle of the transfer of power or access to government, but rather it referred to participation in political life. Therefore, we believe that the political party's definition in Jordan should be consistent with the definition that focuses on the common goal that individuals seek through the party. To avoid thinking about illegal means, parties and political forces may turn to it.

\subsubsection{Political Pluralism of the Left-Wing Movement Before 1957}

The left-wing movement represents the group of nationalist, communist, Baathist, and patriotic socialist parties whose presence on the political scene coincided with its independence. The right-wing trend and the centrist trend contributed to establishing the first pluralism and political participation by participating in the parliamentary elections that produced the first parliamentary government in 1956. The electoral program for this trend formed a political approach with the Jordanian street, nationalist and ideological parties, and Arab countries that were hostile to the Palestinian people's regime and nationalism (Al-Shaer, 1987, p. 119).

After 1989, a new stage of democratization, political participation, and party pluralism began after the promulgation of the Parties Law of 1992, the Election Law of 1993, and the emergence of leftist, national, religious, and conservative parties, most of them are the extension of the parties in the 1950s(Hassanat, 1995: 16). Therefore, the participation of left-wing parties with other parties can be considered an active contributor in supporting multi-party pluralism and achieving a transition to democracy and political participation early in the establishment of the modern Jordanian state, despite the ban on the activity of these parties, which led to the formation of the first multi-party government and political participation from a coalition of several winning parties headed by the National Socialist Party, which achieved the majority of seats in Parliament.

\subsubsection{National Socialist Party}

The National Socialist Party is considered a summary of the national movement's thought and activity after the unity of the two banks. It obtained the license in the name of the "National Socialist Party" as it appears that the Jordanian regime was interested in establishing the party. Because of the presence of many founding members from supporters of the system, they set their goals by besieging the communist tide and the Baath, despite the presence of members of the left-wing (conservative, 1998, pp. 28-29).

The party emphasized in its articles of association at the beginning of the founding that Jordan is part of the Arab nation and to preserve the monarchy, but the party's thought was influenced by the programs of nationalist and leftist ideological parties. And his support for President Gamal Abdel Nasser and the countries that support him because of the political and intellectual support he received from these parties, and the call for an end to the Jordanian-British treaty and the anti-alliance (Harrist, 1958, p. 77). Therefore, despite the shift in the party's 
program and its outlook on the relationship with the Jordanian political system, it contributed to the development of party pluralism and political participation. Through his participation in the elections and formation of the first government to transfer power and political pluralism with right, middle, and left parties in 1956 after the party won the majority of seats in the Fifth Parliament, the political thought of the party formed the core of the national movement and formed with the national parties and other parties a new trend in Jordanian politics based on pluralism and political participation and secreted multi-party.

\subsubsection{Arab Nationalists Movement}

The activity of the nationalist political movement began in Jordan in 1948 in Amman, from the Arab Club, and the leadership of the movement believes that Arab nationalism is the driving force of human history because of its ancient existence before Islam (Qaziha, 1980, pp. 329-335). And they defined their slogan when contesting elections in unity, liberation, and revenge (Shukair, 1991, p. 85). The movement benefited from the atmosphere of political openness in Jordan despite its hostility to the Jordanian government, accusing it of conspiracy and standing against all Jordanian policies.

The movement set its goals in the political program by calling for Arab unity, liberating Palestinian lands' liberation, fighting colonialism, implementing socialism to achieve social justice, and applying democracy to achieve political justice (Al-Adwan, 2014, p. 273).

The Arab Nationalists Movement contributed to the development of political action on the Jordanian scene, and the resulting development of democracy, party pluralism and political participation, and the formation of an active political opposition movement that led to the disruption of democracy and pluralism in long stages after its threat to the Jordanian regime.

\subsubsection{Communist Party}

The beginnings of the Communist Party appeared before 1948 in Palestine with the National Liberation League's establishment as a communist movement in Haifa after the split of the Palestinian Communist Party into an Arab party and a Jewish party. In Jordan, the Communist Party's activity started in 1949 through its relationship with the Syrian Communist Party (Ziyadin, 1981, pp. 28-29).

It was considered the first political party in Jordan that arose on organizational and party ideological grounds with a broad popular base, and its funding depended on what the Soviet Communist Party allocated to Arab communist parties. The Communists opposed rule in Jordan, which led the government to issue the Anti-Communist Law No. (17) for 1948 and law No. (91) for the year 1953 (Al-Adwan, 2014: 130). Nevertheless, after the two banks' unity, the government system somehow overlooked the party's exercise of political activity, which prompted him to participate in the elections of the Parliament in 1956, within the Communist National Front with other political currents and the formation of the government of political pluralism and was the reason for its dissolution. Therefore, the secret and public process of the Communist parties affected the development of partisan experience, pluralism, and political participation, despite its lack of conviction in its application in its ranks.

\subsubsection{Arab Socialist Baath Party}

The Baath Party was established in Syria, where several Jordanian members studying there joined it (Alwash, 1961, p. 48) intellectually and politically spread in Jordan and Palestine, it was only allowed to license in 1954 by a decision of the High Court of Justice (Amnon Cohen, 1988, pp. 322-323). The party's program focused on the internal and regional situation as goals and principles and focused on securing freedoms and democracy and achieving reforms; it gained great popularity among the people on its two shores and determined its electoral program in 1956 to activate political, constitutional, economic and social life. As it resisted alliance policy, their ideas met with the nationalist, leftist, and patriotic socialist parties to implement the liberal democratic policy (al-Sayyid, 1990, p. 117) participated in the pluralist and parliamentary government in 1956.

Therefore it can be said that the party is one of the parties that participated in the development of political thought and established the first partisan and political pluralism stage despite its participation in ending this stage despite the lack of application of participation and the transfer of power in its organization (Al qudah, 1994, pp. 51-52), and there are other parties in effect, such as the Palestinian Arab Party, the Nasserist Movement (Al-Maaytah, 1999, pp. 54-55). And the Arab Constitutional Party directly contributed to the promotion of pluralistic political participation with the current religious parties (Gharaibeh, 1977, p. 72) represented by the Muslim Brotherhood, Hizb ut-Tahrir, and the individual officers' movement. 


\subsubsection{Formation of the Government of Participation and Political Pluralism, 1956-1957}

The stage of the twentieth century's fifties was a period of recovery for multi-party politics in all its spectra and ideologies. A group of currents emerged from it, the religious current represented by the Muslim Brotherhood, which participated in developing political action on the Jordanian scene with other currents. During its development and activities, it formed the first real democracy in Jordan's political history, which was produced by multi-partyism and political participation at that stage (Al-Adwan, 2014, pp. 145-148) after the National Socialist Party achieved the parliamentary majority and the political and ideological parties achieved a remarkable victory in the parliamentary elections for the Fifth Council in 1956AD.

The assignment of the head of the National Socialist Party came in line with the constitution, leftist and nationalist orientation. The demands of the Jordanian political street to form a partial national government got a majority that achieved one of the most important democratic principles and political participation for the first time in Jordan's political history, as the first initiative in which the leader of an opposition party is chosen, he won the elections despite not winning. The Nasserist nationalist trend leads to the formation of a partisan coalition government, which later declared a rebellion against traditional Jordanian politics and its association with the West (King Hussein, 1987, p. 107). The government's formation came on the principle of the transfer of power, representing most of the winning leftist, nationalist, Islamic, and centrist political parties in the Fifth Council in 1956.

It reflected the democratic aspect of the government in partisan participation, and affirming the principle of political pluralism, it achieved many internal and external achievements, and these achievements were at all levels and others. It seems that they were the beginning of the divergence and disagreement between the system and the government due to the different political orientations of each party and the different intellectual references and future aspirations.

\subsubsection{Dismissal of the Participating Government}

King Hussein decided to end the conflict between him and the pluralist coalition government that emerged after the formation of the government and create the appropriate conditions for that, as he asked the government to resign on April 10, 1957, after the coalition government achieved its short period unless any Jordanian government achieved the achievements at the internal and external levels. It seems that it was a reason to accelerate its dismissal after feeling that the pluralistic democratic experience had faded due to the struggle of political wills between the king and the government. As it appears that the government felt tightened its control over the internal situation after guaranteeing Arab support, which qualifies it to run the internal and external political life without returning to the king, as the conflict between the West and the East is reversed, and it turns into a conflict between the coalition government and the regime.

The most important of these issues is the "Eisenhower" principle to counter communist expansion in Jordan (Eisenhower, 1962, p. 83), and the activity of the communist parties in Jordan, and the politicization of the army by nationalist and leftist parties and the international situation, which brought the Prime Minister under the influence of ideological ideas with a nationalist and leftist orientation in the face of the regime, although King Hussein drew the Prime Minister's attention to the dangers threatening Jordan from communism. But the president did not heed these directions (King Hussein, 1987, pp. 108-113) consequently; these measures led to the declaration of martial law (Official Gazette: No. 1327), the dissolution of political parties, the banning of their activities, the arrest, trial, and flight of some party leaders outside the country except the Muslim Brotherhood.

\subsubsection{Pluralism and Political Participation of Nationalist and Leftist Parties 1957-1989}

After preserving the results of these parties from party pluralism, political participation, and a handover of power, it resorted to clandestine work until 1989, the beginning of the transition to democracy and political participation for the second time, as leftist and nationalist parties joined the Palestinian resistance movement after the founding of the Palestine Liberation Organization in Jordan, And started working through it openly without a license. It became competing with the state and the government system with the Palestinian factions and some regional powers to control the political system and government in Jordan, which contributed to the regime's adherence to its anti-party stances of allowing multi-partyism and political participation. And not allowing the return of party activity for fear of repeating the experience of 1957 (Al-Adwan, 2008, p. 406). The nationalist and leftist parties started to restore their political activities. The Arab Socialist Baath Party joined the United Palestinian Organization in 1968. established the organization "Pioneers of the People's Liberation War" (The Thunderbolt), and his leadership, made up of some of the two Jordanian parties, took responsibility for overthrowing the ruling regime. 
The pro-Iraq Arab Baath Party established the Arab Liberation Front, which trusts the Emirate of Iraqi forces in Jordan in terms of material and moral support (Moral Guidance, 1973, p. 31). As for the Arab nationalist movement, after joining the Palestinian commando action, it formed the "Heroes of Return" and the "Revenge Youth Organization" to work on the Jordanian scene where the movement criticized the Palestine Liberation Organization in its policy calling for rapprochement with the Jordanian regime. (Alhujaj, 2001, pp. 333-334). The Arab Nationalists movement was defected (Al-Zein, Al-Nahhas, 1976, p. 33) at the political and organizational levels.

Three new organizations, national and country, were built on its ruins closer to Communism and Marxism-Leninism and Revolution, it formed a weight in the guerrilla work on the Jordanian scene, it also constituted a concern for the Jordanian regime because of the slogans it put forth, "All authority for the resistance" and "No authority over the authority of the resistance." The Popular Front for the Liberation of Palestine was formed as a Marxist-Leninist party organization. The Popular Front for the Liberation of Palestine, the General Command, split from it. Popular Democratic Front for the Liberation of Palestine split from this front. (Abdul Rahman, 1978, pp. 149-154) It affected Jordan politically and economically through its hijacking of foreign aircraft, exposure to security forces, and increased tension with the Jordanian authorities, each of which constituted a new addition to parties and organizations operating within the Palestinian factions in public and openly opposed to the Jordanian regime. As for the Communist Party that exchanged hostility against Jordan (Ziyadin, 1981, p. 410), it was one of the main reasons for ending political participation in Jordan in 1957; its relationship with Jordan has improved after the establishment of mutual relations between Jordan and the Soviet Union, and the issuance of a royal pardon for the convicted and fleeing, initially opposed the guerrilla action, and called for the acceptance of the UN resolutions, which is consistent with the Jordanian regime's orientation in calling for a peaceful solution and support for the regime in Jordan.

However, he soon changed his position and decided to participate with the Palestinian factions, forming a "supporters organization" and calling to establish a national government in Jordan, cutting ties with America, and strengthening relations with the Soviet Union. After 1970, the party suffered several defections until 1985, after which the communist organizations unified in one party (Al-Hajjaj, 2001, pp. 345-346) before 1989, during which the party worked secretly within civil society organizations, especially professional unions.

Therefore, we note that the leftist and nationalist ideological parties failed in their attempts and experiences in establishing democracy, resulting in multi-party partisanship and political participation due to the incompatibility of the goals of these parties with the regime and an attempt to overthrow it. It also set one of its plans to topple these parties and prevent their activities and end political and party participation, so that Jordanian governments became without real legislative authority or licensed political parties until 1992.

During this phase, the Palestinian factions, some nationalist and leftist parties, and their leaders moved to work through professional unions after the governments condoned the activities of the parties during a period of worsening relations between the government and the Professional associations on political action in the unions (Al-Adwan, 2007, p. 441) where the role of political associations in the stage of banning party activity doubled from 1957 to 1989, and the absence of democracy, pluralism, and legislative life. However, this role was considered one of the obstacles to the development of multi-party politics, especially after the splits that struck the left and the nationalist current. This allowed the growing role of the Islamic movement, after its openness to these forces through professional unions in national issues, and these parties in particular, and other parties in general, except for the Muslim Brotherhood movement, could not have an influential role or active presence in Jordanian political life.

\subsubsection{Pluralism and Political Participation of Left and Nationalist Parties After 1992}

Since the beginning of the transition to democracy and political pluralism in 1989, and the promulgation of the Political Parties Law No. 32 of 1992, political parties began to appear in Jordanian political life in public: some of them remained and continued, and some of them disappeared shortly after its licensing among them, joined other parties in a political unit that formed one party. Including what began to fragment after unity, and some parties within it occurred multiple splits at different times. In mid-2004, the number of licensed parties reached thirty-four political parties. In 2019, the number of parties reached 48 (the Ministry of Political and Parliamentary Development), including the leftist nationalist trend, which shifted from clandestine activity to the public, some Palestinian factions have turned into political parties operating openly. (Al-Adwan, 2008, pp. 245-270), It began by calling for the updating of the legislation governing parties, especially the 1992 Parties Law, which did not satisfy the aspirations of parties, and limited their freedom, and was considered an entry point for neighboring countries in the priorities and programs of parties, which called on the government to 
amend the election law in 2005 to introduce the provision of party financing. The subsequent amendments before and after the year 2011, Did not allow these parties to participate in political truth.

\subsubsection{The Participation of Nationalist Parties After 1992}

The national trend was divided and retreated after the Palestinian guerrillas' exit from Jordan and the events that followed on the Arab and regional scene. And it was unable to rise or cohesion and appear on the Jordanian political scene as it was in the pre-1957 stage, despite the transition to democracy and political participation and the issuance of the Political Parties Law in 1992 (Sabah, 2006, p. 39) and the subsequent amendments to party laws until 2015. Therefore, the nationalist and leftist parties are facing a crisis in their organization, and these democratic parties have not really proposed, but have often ignored them and used undemocratic methods inside and outside the party. These methods developed when they came to power (Al-Ma'aitah, 2006, p. 27) in some Arab countries. One of the things that affected the governments 'failure to achieve real political participation is that some national parties' association is intellectually, politically, financed organizationally still transcending Jordan's borders to the Arab region. And its external affiliation (Al-Rantawi 2003, p. 17) made it obligated to adhere to an external agenda and priorities at the expense of national priorities; this led to the decline of the influence of these parties, after the decline of their popular bases, and the removal of the regimes that established them in foreign capitals. Likewise, the national trend is accused of adopting a dual policy while expressing a rush to democracy, political participation, and freedom. It addresses any Jordanian breach of it, as it does not show strength and enthusiasm when suppressing freedom, pluralism, and democracy within the party itself; likewise, it appears that the new party leaderships have retreated from nationalist thinkers and regenerators. Most of the symbols of Jordanian national thought originated outside Jordan in the first place.

Likewise, nationalist parties were unable to produce new traditions in contacting society, and the second Gulf War affected these parties' ability to influence the masses (Masalhah, 1999, p. 109). In contrast, some political thinkers see that problems and negatives are facing the nationalist and leftist tendency in Jordan, such as the role of sectarianism in fragmenting and splitting parties, where nationalist parties revitalized sectarianism, tribalism, and family, Likewise, the defects of the intellectual structure of the national political and intellectual elites (Mhafiza, 2006, pp. 55-56). Also, these parties represented the role of the opposition and the loyalists before 1989 through party-structure structures and their counterparts in the Palestinian factions, while it represented the role of loyalty through dozens of symbols in these parties and their theorists that the Jordanian regime was able to attract, prime ministers, ministers, general secretaries, and senior officials in important centers in the state. (Abu Ghunaimah, 1999, p. 154).

For the national trend to succeed in its quest for pluralism, political participation, and democracy, it is necessary to start from its Jordanian national identity and build confidence with the political system achieving democracy and the rotation of power in its organization, and striving to achieve unity and political participation, and demanding access to a peaceful and legitimate transfer of power, especially in the stage of the so-called Arab Spring and beyond.

\subsubsection{The Participation of the Communist and Left Parties After 1992}

The global transformations in the communist and socialist camp affected the left political parties in Jordan in particular, and the Arab world in general, with the collapse of the leftist ideology that prevailed for nearly a century. The Jordanian left considers the creativity of the Jordanian Communist movement represented by the Communist Party, and the faction of the factional political forces that arose out of the Arab nationalist movement on the Jordanian Marxist left, especially some Palestinian factions such as, the Popular Front, and the Democratic Front, and to which the two parties (the People's Unity and the People's Democratic Party-Hashd) belong to and some of the leftist currents that have separated from them and that belong to the Palestinian, local, or hybrid factions (Sabah, 1996, p. 41).

The Jordanian Communist Party did not apply the principle of democracy and participation within the party, and the differences within the party led to widespread splits. Other parties such as the crowd and popular unity suffered from the defections because of the rejection of democracy and the external link organizational. The dispute is also centered on the affiliation of the left parties with national issues and the Palestinian issue at the expense of the internal social, demand, and political struggle (Madanat, 1999, pp. 114-121).

In line with the modern stage, these parties have modified some of their conditions to align them with the Jordanian Political Parties Law of 1992 and the Jordanian Constitution. However, it could not fundamentally and effectively restructure its organizational structure to suit the current public needs and democratic transformations 
in Jordan and the Arab world; it remained in its minds to address the future in the international circle of the Soviet Union. (Malkawi, 2006, pp. 42-44).

That is why the leftist trend continued to face (Al-Ma'ita, 2006, pp. 28-29) some challenges, including Not to put forth a clear national-patriotic slogan that is consistent with the international slogan, and the lack of unity of economic orientation with social and political, and a move away from the reality and level of development of Jordanian society, and the lack of adoption of national political, social and economic realities, as a source for building national political and economic programs and relying on the external reference as an origin, basis, and source of knowledge, and the failure of the democratic central class to provide an advanced democratic system for internal party life.

The parties turned into patterns of totalitarian rule. These parties did not absorb the lessons of the product of their lack of democracy, the weak relationship between the parties in the masses, the party leaderships cling to power inside the party, and the loss of their ability to renew, and the many rifts within the left parties as a result of the confusion of the course of this trend, the conflict, subjective and non-programmatic competition between the parties to this trend, and the relationship that was centered on leading and exporting the mass movement organizing its institutions (Al-Hourani, 2004). Therefore, we find that the exit from the secret to public work directly affected the exposure of the left parties' intellectual, political, and organizational situation. Its lack of a coherent left-wing ideological rhetoric that can formulate programs that can garner support, and offering confidence with the political system despite its entry into the twenty-first century and its contact with the Arab Spring and the resultant adaptation of the political system to the demands of the "political and party acceleration movement." In addition to the introduction of constitutional amendments and political reforms, some believe that the left movement crisis is due to its leaders, its composition, class, and intellectual affiliation first since these leaders came from the upper classes in the middle class. There is also a significant loss of the left and needs to be corrected, and those demanding reform must begin to correct themselves first (Al-Nahhas, 2005).

And this stream still lacks democracy and participation within its organizations, which has made it vulnerable to successive splits. Also, the party is still suffering from the political elite's intellectual crisis related to the past. The party did not attempt to reconsider the socialist democratic experience to reach an institutional democratic model with constants with democratic development and international reality. In contrast, some leftist parties, especially the Palestinian factions, have non-Jordanian organizational ties under the political system's consideration and approval.

Jordanian Communist parties call for democracy, political participation, and the transfer of power without stopping at the merit that they must pay in their internal structures, as long as they call for democracy and pluralism, and this is not done (Rimawi, 2006, p. 55).

From this, we note that these new old parties still consider that their opposition to the state and order and the support they received from some social groups constitute a political program. Yet, at the same time, it did not maintain its popular base, and the departure from partisan activity in favor of other activities became evident, which affected the process of political participation within these parties and at the state level. Despite the importance of these parties in the political process and the development of political life in all stages of Jordanian political life, which are required to unite their ranks and return to their mass and organizational base with one unit and one stream, through which they can reach the circulation of power, and impose pluralism and democracy with other political currents.

\subsubsection{The Political System and Political Participation of Nationalist and Leftist Parties}

The political system in Jordan was and still is afraid of political participation based on partisans in general and leftist and nationalist parties in particular, because of the declared and secretive objectives of these parties hostile to the regime, and their association with regional and international states and systems that rivaled the Jordanian regime's hostility since the beginning of the Cold War in the early 1950s until the decline of Arab nationalism, and the collapse of the communist regime in 1991, and continued even after the Arab Spring. Although these parties were not licensed and two laws were issued to resist communism, the first was in King Abdullah I's era in 1948 and the second in the era of King Hussein in 1953. The Jordanian regime in the mid-fifties allowed leftist and nationalist parties to operate publicly under pressure from several internal, regional and international factors, in an attempt by the regime to ward off the dangers that surround it and to maintain its stability and continuity, which established the first real partisan political participation in Jordan that resulted in the establishment of the first parliamentary government in 1956. This government did not last more than a year, which ended due to the struggle of political wills between the left and nationalist parties and the government, and between the regime. (Al Adwan, 2014, p. 173). 
Successive Jordanian governments did not lift restrictions and bans on the left and national parties or party activity throughout martial law and exceptional laws until 1989, interspersed with the Palestine Liberation Organization's attraction to left and nationalist parties, which contributed to the regime's fear of increasing its role on the Jordanian scene after it became competing with the political authority and its demands to bring down the regime.

Its presence posed a threat to the system of government and the Jordanian state (Al-Lassamah, 2003, pp. 115-117), and it finally came to an end because there is no compromise between them and the removal of these organizations and parties from Jordan. Therefore, successive governments in Jordan have put legislation and regulations that restrict the participation or licensing of leftist and nationalist parties in their defense of the political system in general. And chasing these parties and restricting their members and arresting them. And prevent party activity for more than 30 years.

In 1989 Jordan witnessed a new transformation in its political system due to several internal, regional, and external factors and the most important of them is the economic crisis that led to a political crisis, which the government system noticed and tried to absorb before its danger spread after it almost obeyed the Jordanian entity as a political system. And a system of rule, the king responded to the popular and political opposition, democratization and political participation, "that the next stage will be new not only for the resumption of democratic parliamentary life but for the responsibilities we will share (King Hussein's speech, 1988-1994)."

This approach of the government system to allow political participation in political life is an attempt to involve the parties in easing regional and internal pressures affecting the legitimacy of the system, as it allowed the first legislative elections to take place in 1989 political parties participated in public. However, they were not licensed and participated in making decisions effectively and issuing democratic legislations. This stage witnessed a rapprochement between the ruling regime and political forces, and between the political forces themselves, and we enable the system to maintain its stability and continuity, even though these parties did not achieve democracy, participation, and the transfer of power within their systems and institutions. It seems that the success achieved by the parties in the elections in 1989, the abolition of exceptional laws, and the adoption of laws governing public freedoms, including the Law on Parties, it was a reason for governments to restrict party political participation in the absence of the legislature after amending the 1993 Election Law, and the adoption of the one-vote law that gave governments the right to exclude partisan opposition, including Islamism, nationalism and the left, to pass the peace process with Israel. The effect of this exclusion appeared in the 1993 elections after the apparent decline in the results achieved by the parties in these elections (Al-Zoubi, 2001, pp. 58-63).

Despite what governments announce in their statements and statements by officials of assurances of political participation and support for parties, the government retreat was evident after the signing of the peace treaty on October 26, 1994, which faced popular and partisan opposition. Especially from the nationalist, leftist and Islamic parties led to the formation of the "Anti-Normalization Committee with Israel" (Al-Khatib, 2005, pp. 14-15) that affected the political situation, and it was a source of concern for the Jordanian system and governments, where the government opposed the holding of any anti-normalization conference prepared by these parties, as it was inconsistent with state policy. The government's actions have reached the point where the High Court of Justice has ruled that this committee is illegal under a Legislation Bureau memorandum. (Al-Khasawneh, Bakr, 2003, pp. 62-63). On the level of government opposition to the activities of these parties, King Hussein talked about Jordan's experience with ideological parties, and he said (Al-Tal, 2013, p. 36) The rules of these parties are governed by the positions and orientations of their leaders outside the country, as their authority, funding, programs, and goals are not Jordanian.

In another speech, King Hussein criticized the attempt by some to monopolize the truth, to exploit the climate of democracy and tolerance, to violate the laws of the country, to offend its image, or to abuse its symbols and institutions (Al-Adwan, 2008, p. 330) About the parties and currents involved in establishing the Anti-Normalization Committee, and a continuation of the government's approach to restricting the political participation of ideological parties, King Abdullah II did not hide the problems Jordan faces from the opposition in the Jordanian street by establishing the so-called anti-normalization committee by opposition parties and describing them as a minority that most people are coerced with specific positions (Al-Tal, 2013, p. 32). Therefore, we note that the political system at the level of the system of government and governments in its dealings with leftist and nationalist parties takes into consideration how to restrict them and prevent their participation in political life, despite his statements regarding the transition to democracy and political participation over the past years to avoid the dangers that may occur from one side and to try to draw the attention of these parties to correct their organizations and goals and to start from the ideology and national interest, and reconsider their ideology. 
Despite this view of the parties, their crisis with the political system, and their accusation of not showing their national identity, the government system used a dual language in dealing with these parties. He tried to appease and attract these parties by involving their symbols in governments as ministers, secretaries-general, and senior officials in important centers in the state (Abu Ghanima, 1999, p. 154). It also overlooked some left and nationalist parties' activities that fall under the umbrella of the Palestinian factions and have non-Jordanian organizational ties (Al-Adwan, 2008, p. 228).

Government efforts to accommodate these parties have yielded no results. The fact that the regime in Jordan did not offer what gives left and national parties a role in real political participation, and repealing the one-vote law, although the government affirmed more than once its intention to amend the election law, the most recent of which was Law No. 34 of 2001 and Law No. 11 of 2003 that did not repeal the Single Voting Law that restricted political participation. As a result, the Higher Coordination Committee of the opposition parties rejected these amendments; they filed a lawsuit with the Supreme Court of Justice for violating the law. However, the court dismissed the case on the pretext of lack of jurisdiction (Adwan, 2008, .p. 288).

Therefore, governmental measures constituted an impediment to nationalist, leftist, and opposition parties' political participation in more than one field of participation. Parliamentary elections after 1993 until 2007 saw the ideological parties boycott political participation. In an attempt to reform what was corrupted by governments, King Abdullah II put forward several reform projects, including the political development project, and directing governments to prepare laws that contribute to the success of the process and political participation, including the law parties. The election law, to achieve political openness to all groups of the people and the participation of parties; however, governments are trying to implement the reform agenda that enables parties to participate in politics, Enact restrictive legislation, and disabled political participation in developing parties under the consideration and approval of the regime (King Abdullah II speech, 2004, pp. 107-114).

This means that governments' discourse to disrupt political participation is consistent with the trends of the regime in its response to the left parties due to the previous ideas and experiences they carry with them. Still, he was able in all these critical stages that the system faced because of these parties, he managed to avoid their dangers by opening up to these parties and involving them in political life to reduce these dangers and continue the system.

\subsubsection{Controls of Participation and Political Pluralism of Nationalist and Leftist Parties}

By the establishment and organization of political parties several laws since independence until 2015 some of the provisions of these laws have contributed to the establishment and organization of political parties, while other items contributed to the decline and restriction of political participation of the parties in general and the leftist and nationalist parties in particular. These parties formed a source of concern and threat to the political system and accused it of belonging and directing from abroad.

If we exclude the laws of political parties that ruled the fifties of the twentieth century until 1989 , then the first law of parties No. 15 of 1995 came, and subsequent laws up to the 2015 law restrict freedom of party activity in some of its articles. Law of Parties No. 32 of 1992 has been passed (Al-Tal, 1999, p. 17). After consensus on the National Charter by all the political parties that paved the stage for democratic openness in 1989 As opposition parties became accepted by the regime while retaining the possibility of being restricted at any moment.

Despite the assertion in the National Charter that the laws governing the operation of political parties may not contain provisions that openly or implicitly disrupt the constitutional right to the establishment of parties and that parties or their members may not be linked organizationally or financially to any non-Jordanian party, however, the Parties Law of 1992 established several political, financial and security restrictions and restrictions that limit party development. It also set several political controls in these parties' faces (Law of Parties, 1992). The law provided for equal opportunities for all citizens when assuming responsibility or participation in it, and the lack of organizational or financial association with any non-Jordanian party, or directing partisan activity based on orders or directives from any foreign country or party and refraining from organizing or party polarization in the ranks of the armed forces, security services, and the judiciary and in state institutions and public institutions, the prohibition of establishing military or paramilitary formations. Everyone who violates this faces a two-year prison sentence, a fine not exceeding two thousand dinars, or both penalties (Party Law, 1992).

These controls may be acceptable to some extent to find national parties that originate from the homeland and are concerned with national issues and policies. What is meant by this text is that the left, nationalist, and ideological parties are not related specifically to any external party due to the interface of the system, and so that they are not affected by external orders, and this applies to the non-establishment of military or paramilitary formations. It has been interpreted as the aim of the lack of duplication of affiliation between workers with 
Palestinian political and military factions due to the lack of separation between Palestinian political action and partisan action (Alqadi, 1993, p. 43).

In excluding some forces in the political system from exercising a political role, such as the military, it is considered a guarantee of their neutrality. As for other groups and forces, their entry into political participation is necessary for democratic systems (Bouhannah, 2011, p. 28). In Jordan, we find that the government institution is equal in terms of restriction or prevention with political participation between nationalist and leftist parties, and the military establishment through laws and legislation restricting the participation of these parties and the armed forces in most stages of the development of political life in Jordan.

As for security challenges, successive governments have resorted in many stages to confronting leftist and nationalist parties, and fabricating cases against it, and resorting to the arrest of its affiliates, and exposure to the freedoms of citizens who join them by chasing down its members, whether in government institutions or universities, arresting some of them, and converting some of them to state security courts (Khair, 1999, p. 97). This is confirmed by some studies on the challenges these parties face by governments by not encouraging affiliation with or affiliation with political parties, because of its experiences with these parties in addition to many objective and subjective challenges (Center for Strategic Studies from the University of Jordan, 2003, p. 7).

The opposition parties demanded the government to issue a law allowing political participation and the transfer of power, although it does not take the handover of power within its regulatory frameworks. However, the government issued (Law of Parties No. (39) for the year 2015), which established party supervision for the Ministry of Political and Parliamentary Affairs in place of the Ministry of the Interior and required the party to adhere to the principles of the constitution, provided that the foundation is based on citizenship and respect for pluralism. The number of founders was limited to 150 members, and he maintained the conditions of non-affiliation with any non-Jordanian party and other conditions previously mentioned in the laws of parties.

From all of the above, we find that successive governments, from 1957 until 2019, a step towards the nationalist and leftist parties, take into account the restriction of their activities. It avoids parties 'opposition to these laws and their negatives or stipulates the parties' role in political participation and the transfer of power, in the sense that the political system, in general, is still possessed by suspicion of the activity of nationalist and leftist parties, and lack of confidence in their leaders who could not change their attitudes, ideas, and goals, also, the development of an electoral or party law in the absence and participation of parties and opinion-makers in its situation it is a retreat from the process of democratization and political participation, and giving the executive authority the right to overrule all powers, including political parties, restrict the right to political participation, control sectarian and family loyalties and political money, and forge the will of the people and participants in the political process.

\section{Conclusions}

- In all its national, communist, and Baathist spectrum, the leftist movement took advantage of the atmosphere of political freedom after independence until 1957 and established with other political currents the first political participation and pluralism and the formation of a short-lived parliamentary government due to the conflict of wills between these parties and the political system.

- International and regional factors and internal events in Jordan in 1989 constituted a significant turning point for the shift towards participation and political and party pluralism for all political currents, especially the left-wing political current that benefited from this transformation.

- Laws regulating political and party life remain an impediment to the handover of power and partly political participation. In the leftist and others for reasons related to the political system and the left-wing itself.

- The regional, international, material, moral, and political support these parties received enabled it to impose its political will on the ruling political system in stages, and this will retreat in other stages before and after the Arab Spring.

- The transition to democracy and political participation came as an attempt by the regime to engage leftist and nationalist parties and participate in its attempts to face internal and external challenges, up to the Arab Spring period and beyond.

- The transition to political pluralism was not a political choice, neither for the system of government nor political parties. The system of government, through laws, regulations, and legislation, attempted to restrict the political and partisan activity of the left and nationalist trend, as well as It was not a political choice for nationalist and leftist parties through its intellectual, organizational, material, and moral ties to regional and 
external entities that do not believe in democracy and political participation.

- The international, regional, and internal transformations and the collapse of the socialist and communist system were not an incentive for the leftist and nationalist parties later to renew their popular and mass bases, and it did not understand the lessons of its lack of democracy, Party leaders hold power within the party, or develop a coherent ideological discourse.

- In addition to the preceding, there are several political, financial, legal, and personal challenges facing political parties in general and leftist and nationalist parties in particular that have been enacted by successive governments.

\section{References}

Abd al-Rahman, A. (1978). The Palestine Liberation Organization has its roots, its foundations. Palestinian Liberation Organization Research Center, Beirut.

Abu Ghanima, Z. (1999). (symposium) The Jordanian Democratic Path, Where to? New Jordan Center for Studies and Publishing, Amman.

Abu Nawwar, A. (1990). When the Arabs Faded, Memoirs of Arab Politics 1948-1964. Dar al-Saqi London.

Al-Adwan, A. H. M. (2013). Democratic Transition in Jordan 1989-2010. Al-Sayel for Publishing and Distribution, Amman.

Al-Adwan, A. H. M. (2014). Evolution of partisan experience in Jordan, 1921-2007. Dar Al-Raya, Amman.

Al-Adwan, A.-H. (2007). Political Pluralism in the Hashemite Kingdom of Jordan 1921-1989 (Part 1). Pioneers Center for Publishing Studies, Amman.

Al-Adwan, A.-H. (2008). Political Pluralism in the Hashemite Kingdom of Jordan, 1989-2006 (Part 2). Al-Raya Publishing and Distribution House, Amman.

Al-Arab newspaper today (November 30, 2006).

Al-Dustour Newspaper (June 25, 2006).

Al-Hajjaj, K. I. (2001). History of Jordanian Political Parties 1946-197. Author, Amman.

Al-Harahsheh, W. (2006). The Evolution of Political Life in Jordan 1991-1992. Al-Yazouri Publishing and Distribution House, Amman.

Al-Hourani, H. et al. (1995). Guide to the Political Party. New Jordan Center for Studies, Amman.

Al-Hourani, Y. (2004). Features of the Crisis of Political Parties in Jordan. Al-Rai newspaper, September 8.

Al-Khasawneh, Z., \& Bakr, F. (2003). Trade unions and civil society institutions in Jordan (symposium works). Al-Quds Center for Political Studies, Amman.

Al-Khatib, J. (2005). Syndicates in Jordan, Crisis, and Dimensions. Al-Quds Center for Political Studies, Amman.

Al-Khatib, N. (1983). Political parties and their role in current government systems. House of Culture for Publishing and Distribution, Cairo.

Al-Lasasmeh, H. (2003). Political and military developments on the Jordanian scene, 1968-1974. Dar Al-Khaleej Publishing and Distribution, Amman.

Al-Ma'aitah, M. (1999). The Army in the 1950s, (Seminar) Suleiman Al-Nabulsi Government, 1956-1957. The New Jordan Center, Amman.

Al-Maayta, M. (2006). The Crisis of Democracy in the Structure and Thinking of Arab Political Parties (Seminar) Political Parties in the Arab World, Present Reality and Future Prospects. New Jordan Center for Studies, Amman.

Al-Mashat, A.-M. (1988). Political Development in the Third World, Theories and Issues. Al-Ain Foundation for Publishing and Distribution, Al-Ain.

Al-Mousa, S. (1986). Flags from Jordan, Hazza Al-Majali, Suleiman Al-Nabulsi, Wasfi Al-Tal (Part 1). Dar Al-Shaab, Amman.

Al-Nahhas, S. (2005). The Jordanian Left, Merchandise and Suffering a Leadership Crisis. Al-Duster, January 18.

Alqadi, A. (1994). The Political Crisis in Jordan, 1957-1958 (Unpublished Master Thesis). Yarmouk University. 
Alqadi, A. T. (1999). The Political System and Political Participation of Parties in Jordan, Study of the 1993 Elections (Unpublished Master Thesis). Al Al-Bayt University.

Alrabie, F. (2004). Democracy between theoretical rooting and the political approach. Al-Hamid Publishing House, Amman.

Al-Rantawi, A. (2003). The national trend in Jordan (in) Jordanian political parties, reality and ambition (conference proceedings). Al-Quds Center for Political Studies, Amman.

Al-Rayes, R., \& Al-Nahhas, A. (1976). Dina Al-Masar Al-Saab, Palestinian Resistance, Its Organizations, Persons, Relationships. Dar Al-Nahar for Press Services, Beirut.

Al-Rimawi, M. (2006). Dialogues and interventions of participants (symposium) Jordanian political parties, reality and ambition. Jerusalem Center for Political Studies, Amman.

Alshaaeir, J. (1987). A politician remembers experience in political work. Riad El-Rayes Publishing, London.

Al-Sharif, M. (1986). Communism and the Arab National Question in Palestine.

Al-Tal, A. Y. (2013). Changing the principles of strategy is the path to real reform in Jordan. Author, Amman.

Al-Tal, S. (1999). Jordanian National Charter, Philosophy and March. Al-Rai Library, Amman.

Al-Tamawi, S. (1979). The Three Powers in Arab Constitutions and in Islamic Thought. University House, Cairo.

Al-Zoubi, K. (2001). 12th Parliament - 1993-1997 (Settings). Documentary Publications, Parliament, Amman.

Al-Zoubi, S. (1995). Political Parties and Parliament, The Jordanian Experience (in) The Guide to the Political Party (Workshop). New Jordan Center for Studies, Amman.

Bouhannah, G. et al. (2011). The Election and the Democratic Transition Process in Contemporary Arab Experience. Dar Al-Raya, Amman.

Collective author. (2010). Jordanian parties and human rights: Analysis of the core charters' content. National Center for Human Rights, Amman.

Doverge, M. (1992). Political institutions. George Saad translation, University translation for studies and publishing, Oman.

Eisenhower. (1962). Eisenhower's Memoirs. Translated by Hubertbergmann, D.N.

El-Baz, D. (2000). The Right to Participate in Political Life. Arab House of Thought, Cairo.

Eliwa, M., \& El-Sayed, M. (2008). The Concept of Political Participation. Damascus Center for Theoretical Studies and Civil Rights, Damascus.

Huntington, S. P., \& NelsonJoan. (1976). No Easy Choice Political Participation in Development Countries, USA.

Ibrahim, S. (1984). Sources of Legitimacy in the Arab Systems of Governance. The Arab Future No. 62, from April 6.

Khair et al. (1999). Challenges are facing partisan work in Jordan. Al-Reyadah Information Center, Amman.

King, H. (1987). My Profession as King, Royal Conversations. Ghazi Gharabel translation, Egyptian Distribution Corporation, Amman.

Law of Parties 1992 No. 32.

Lucian, W. (1960). Aspects of Political Development. Boston little Brown and company INC.

Malkawi, I. (2006). Dialogues and participant interventions (symposium) Jordanian political parties, reality, and ambition. Jerusalem Center for Political Studies, Amman.

Masalha, M. (1999). The Partisan Political Experience in Jordan, A Comparative Analytical Study. Demo fifties and nineties, Dar Wael, Amman.

Mashaqbeh, A. (2003). Jordan's Political System, The Democratic March. Edition 7 Dar Al-Hamid Publishing, Amman.

Medanat, I. (2006). The Socialist Movement in Jordan Through Half a Century (Seminar) Parties and Political Pluralism in Jordan. Abdul Hameed Shoman Foundation, Amman.

Moral Guidance in the General Command of the Armed Forces, Fedayeen between Apostasy and Suicide (1973). 
Muhafazah, A. (1998). Research and Views in Modern Jordan History. Al-Faris Publishing House, Amman.

Muhafazah, A. (2006). Dialogues and Participant Interventions (in) Jordanian political parties, reality and ambition (Seminar) Jerusalem Center for Political Studies, Amman.

Political Parties Law, No. 39 of 2015.

Sabah, S. (2006). The Jordanian Left, Roots of the Predicament and Questions of the Future (in) Jordanian Political Parties Reality and Ambition (Seminar) Al-Quds Center for Political Studies, Amman.

The Democratic Public Opinion Unit in Jordan (2003). Center for Strategic Studies, University of Jordan, July.

The High Discourse of His Majesty the Hashemite King Abdullah II Ibn Al-Hussein. (2004). Volume Three, The Royal Court.

TugeGerald Sparow. (1960). Hussein of Jordan. George GHarrp and GO. Itd London.

Ziyadeen, Y. (1981). The Beginnings, A Biography, Forty Years in the Jordanian National Movement (2nd ed.) Dar Ibn Khaldoun, Beirut.

\section{Copyrights}

Copyright for this article is retained by the author(s), with first publication rights granted to the journal.

This is an open-access article distributed under the terms and conditions of the Creative Commons Attribution license (http://creativecommons.org/licenses/by/4.0/). 